\title{
Research on Academic Management of Universities from the Perspective of Governance
}

\author{
Nan Ding \\ School of Humanities and Law \\ Northeastern University \\ Shenyang, China \\ Shenyang Conservatory of Music \\ Shenyang, China
}

\begin{abstract}
From the research perspective of governance theory, in-depth analysis on the existing problems in the university academic management was carried out, and the measures for the governance of academic management were put forward from internal and external aspects, aiming to guide the reform of university academic management system, and promote the healthy and orderly development of university academics.
\end{abstract}

Keywords-university; academic management; governance; polycentric system

\section{INTRODUCTION}

With the coming of 21 st Century, under the influence of economic globalization, the pace of social development is accelerating, and the university plays an important role in social development. Throughout the "first-class universities" in United States, Britain, France, Russia, Japan and other countries, after in-depth study, it is found that these worldclass universities have the main feature of focusing on academics. The academic level reflects the level of university running, and academic success lies in academic management. Today, under the advocacy of academic freedom, and the concept of academic autonomy, the world university academic management has emerged some problems correspondingly, causing adverse effects on the university's academic reputation, and hindering the development of university discipline construction.

University academic management is the core of university internal management, the characteristic requirement of university organization management, and the internal logic requirement of university. Affected by the traditional management mode of the university academic management, both the government's macro-management of the university and the university's internal micro-management have a narrow understanding of university academic management, which is only regarded as the management of university's own academic affairs. In macro-management, the government treats the university as its affiliated administrative agency for management, while in the university's internal management, bureaucratic administrative management mode is very prominent, so that many discordant voices have appeared in the academic management which occupies a leading position in the university internal management, exposing many problems hindering the healthy development of university academics. The existence of these problems is bound to make us have a deep reflection on the original university academic management mode, and find a new management theory to guide the reform of university academic management system.

In this case, since 1990s, the governance theory developed in the Western countries has provided an effective theoretical support system to solve the problems existing in university academic management. As an innovation of management theory, the governance theory believes that the university academic management should not adopt the single top-down administrative management mode, and the academic management problems must be solved by a joint force of bottom-up cooperation. For the external governance, we should give full play to the governance functions of the government, universities, social organizations and other authorities.

\section{CONNOTATION AND CHARACTERISTICS OF THE GOVERNANCE THEORY}

Since the world bank first used the " crisis in governance" to summarize the situation in Africa at that time, the word "governance" became more and more widely used by the social science community. Since 1970s, governance has been mainly used in public affairs related management and political activities. Since 1990s, along with the re-exploration of management modes by the nation and social public affairs, the "good governance" banner is introduced and "governance" has gradually become a theory with rich connotation and wide application range, such as the currently proposed local governance, university governance, corporate governance, national governance, global governance, making it become one of the most popular international academic frontier theories. In recent years, through the practice of political, administrative and public management reforms in many countries, the governance theory has not only involved a more perfect theoretical framework and logic system, but has also formed a set of standards for the value evaluation of social development and management quality.[1] Just as Hewitt, the deputy director of UN social development research institute, pointed out, "it is difficult for the publications on development issues of today's international multilateral and bilateral institutions, academic 
organizations and private voluntary organizations to exclude "governance" as the common vocabulary." [2]

Governance in English derives from Latin and ancient Greek, meaning control, guidance and manipulation. Governance is a concept with rich practical value and rich connotation in economics, politics, management and international politics. In various definitions of governance, the definition of "governance" given by the Commission on Global Governance is the most representative and authoritative. In 1995, the Commission on Global Governance made the following definition on governance in "Our Global Partnership" report: "governance is an integration of multiple ways that various public or private individuals and institutions manage their common affairs, it is a continuous process that makes the conflicted or different interests reconcile and take joint actions. It includes both formal rules and rules that force people to obey, and a variety of informal institutional arrangements that people agree or think to be in line with their interests. It has four characteristics: governance is not a set of rules, nor a kind of activity, but a process; the basis of governance process is not control, but coordination; governance not only relates to the public sectors, but also involves the private sectors; governance is not a formal system, but a continuous interaction." [3]

From the concept of governance, we can find that governance theory has the following obvious characteristics: (1) the governance theory believes that government is not the only national power center, various agencies once approved by the public can become social power center (centers). Therefore, governance means social public institutions and actors from the government but not limited to the government; (2) in the process of emphasizing the cooperation between the government and the society, governance has blurred the boundaries and responsibilities between public and private institutions, it no longer adheres to the exclusive rights of the state functions, but emphasizes the interdependence relationship between state and society organization; (3) governance emphasizes the participation of the management objects, hoping to form a self-organizing network in the management system, to strengthen the organization and autonomy, also called self-governing, within the system.

\section{CURRENT SITUATION AND PROBLEMS OF UNIVERSITY ACADEMIC MANAGEMENT}

University is a place to study theories and cultivate talents, and its basic features can be summed up in a word: academics. Academics is the foundation of university, and its success or failure lies in academic management. University academic management is implementing regulation and norms of limited academic resources (human, finance and properties) of and academic behaviors by the university in certain time and space, on the basis of academic development and academic special rules, through organization and coordination of others' joint activities, to achieve university academic goal, so as to effectively realize the university academic goal. It has the characteristics of management diversity, management democracy, management authority, management scientificness, management autonomy and competitive management environment. From the perspective of governance, there are a lot of problems urgently needing to be solved in academic management; those problems have affected the function implementation and system innovation of university academic management. Specifically, they are summarized as the following aspects:

\section{A. University Academic Management Is Strongly Influenced by the National Administrative Management System, Lacking Autonomy.}

University academic management should be relatively independent and free, and good academic management atmosphere is the condition of breeding valuable scientific research results. However, from the perspective of world university management system, university academic management lacks autonomy. On one hand, the internal management system of university is an infiltration or copy of national administrative management system in the university, which strictly applies the management mode of the government. From the principal, to the dean, to the director of department, to the head of the teaching and research section, and to the ordinary teachers, a tight organization similar to the Pyramid is formed, the core functions of the university teaching and research are painted with serious administrative color, which has undermined the academic autonomy. On the other hand, academic management autonomy is manifested in the penetration of "official-oriented" thought into academic affairs. Although some people are in the academic activities and management, they are immersed in non-academic pursuit, and have polluted the academic pure land. In academic management, the corresponding management institutions always follow the "top-down" administrative management mode, the university functional departments have relatively great right to decide academic development direction, staffing, research topics and other academic issues, while the grassroots management institutions and teachers who are the most familiar with university teaching and scientific research have no right to speak, only in a position under command and management.

\section{B. The Procedures that Professors Involving in Academic Management Are Imperfect, and They Have Limited Roles}

Major decisions in university management, should be made by inviting experts for demonstration, the professors generally have no right and chance for participation, although some leaders are professors and scholars, they often appear as administrative officials, and inevitably deal with the issues from the administrative aspect. The dean and director of department, as the representatives of academic power and administrative power, are also inclined to administrative power in dealing with the relationship between academics and administration. Because the dean and director of department are both appointed by superiors, responsible to the superiors, as middle-low-class executive representatives, they tend to consider more of the administrative effect and administrative interests in the decision of affairs. Therefore, administrative power is the center in all levels, the roles of professors cannot be played. 


\section{Academic Corruption, and Academic Anomie Phenomena Occur from Time to Time, without Sufficient Autonomy}

With the continuous improvement of the market economic system, teachers' scientific research team has been growing, academic freedom and the concept of university autonomy continue to penetrate, and universities in academic research have made remarkable achievements. But we must be aware of that if there has no effective operating mechanism, some bad phenomena will appear, a few people will violate the basic academic morality, become flighty and impetuous, and unsettled to do practical research, some teachers only pay attention to "quantity" and ignore "quality" in order to complete the task of publishing short, smooth, and fast papers. More seriously, some even "copy" for title promotion, seek quick success and instant benefits, plagiarize others' achievement, or pay others to write articles, or provide false signature; some even crudely complete a paper, tamper and falsify research data, those academic corruption and academic anomie phenomena have all hindered the smooth development of the academic research. Seeing from the phenomena disclosed by media, including academic research, academic fraud, repeated construction, academic bubble, academic inbreeding, treating academics as tool, political academics and other phenomena, it should be said that the current academic community has reached a consensus on the defects and negative impacts of university academic management mechanism. In the university campus, there also exist academic corruption and academic anomie phenomena from the general undergraduate students, graduate students, doctors to well-known professors, and scholars. Therefore, strengthening the construction of academic morality, regulating academic behaviors, and promoting academic integrity, are important tasks for the reform of university academic management system.

\section{GOVERNANCE MEASURES FOR UNIVERSITY ACADEMIC MANAGEMENT UNDER THE VIEW OF GOVERNANCE}

Based on the above analysis, the author thinks that to improve the university academic management, we should focus on the goal of good governance of university management, construct polycentric cooperative governance system, improve the internal and external governance mechanism of university academic management, and promote the university academic management to development towards a healthy and orderly direction.

\section{A. Internal Governance of University Academic Management}

1) Promoting professors' discourse right in university academic management, breaking the ice for university academic management reform: Improving the university academic management mechanism, and changing the traditional mode of "academic administrative management". The thorough reform of university management system will face many problems currently. This involves interest differentiation and integration of various parties, and the university professors have weak consciousness in exercising and safeguarding their rights, therefore, for the university academic management system reform, we first have to weaken the relationship between academics and administration. The institutionalization, standardization and procedure of university administrative and academic management are the basic requirements to achieve the overall goal of university. Due to the long-term influence of "official-oriented" thought, similar to the government, the university is used to establishing the organizational structure by the administrative management pattern. The tendency of university administrative management is relatively serious, which affects the implementation of academic power and the own characteristics of university. Therefore, it is necessary to further clarify and standardize the functions of academic management and administrative management.

Secondly, perfecting "professorial governance" system. "President governs the university while the professor governs academy ", only strengthens the respective responsibilities of administrative personnel and academic staff, and avoids the situation of layman leading experts, rather than strictly separates them. In fact, in colleges and universities, administrative management and academic activities are often combined together. The university takes academic activities as the main activities, from this perspective, the administrative management should fulfil logistics guarantee and management coordination work for the academic activities, ensure the normal development of academic activities, and give the academic rights back to the hands of professors.

2) Setting up a good academic management science evaluation atmosphere, and actively promoting high-quality and instructive academic management mechanism: First of all, we should give full play to the discourse right of specialized committee, discipline committee and academic organizations of the university in the evaluation process of academic management, establish polycentric cooperation management system, and achieve " professionals manage their own trades", transforming from management to governance. Secondly, we should reduce the phenomenon of focusing on quantity and ignoring quality in academic achievements evaluation and talent selection. By increasing attention of paper retrieval rate, anonymous review system is implemented in academic achievement awarding, scientific research subject establishing, and degree evaluation and other issues which are directly related to the vital interests of scholars, and a set of scientific and reasonable talent evaluation and academic evaluation system is formulated, so as to perfect the academic management mechanism.

\section{B. External Governance of Academic Management in University}

1) Repositioning the role of government: The role of the government should be repositioned in the governance process of university academic management, and the government should focus on macro management for university academic management. The government should change its function, from direct administration of the university, into the use of legislation, funding, planning, information services, policy guidance and the necessary administrative means, for macro management. The government should not directly manage and control the operational links and processes within the university, and should not abuse the executive will and administrative orders in the academic field. The management of government on the university academics should be macro 
management, if the government pays too much attention to the micro management of the university academics, it will definitely weaken and even damage the government's macro management functions, and will also affect the academic freedom and autonomy in running a university which should belong to the university itself. The government's macro management of university academics involves two aspects, one is asking the government to play the goal-oriented function for university academic development, namely, the development direction, development strategy, quality standards, existing problems of university academics and measures for solving these problems in the future long period, it should have a macro planning. The other is perfecting the legal system construction of university academic management, establishing a reasonable allocation of rights between the government and the university academics, perfecting the control mechanism of laws, and regulating the academic activities by laws, regulations and some issued guidance documents. The government formulates laws and regulations, and guides universities to establish and gradually improve the university governance structure.

2) Establishing partnership between government, university and society: University is a stakeholder organization, the interests of all stakeholders should be considered when the university makes a decision. For a long time, higher education which is a quasi-public good monopolistically produced and provided by the government. As a result, not only the public resources are not effectively allocated, the quality of public goods or services cannot be guaranteed either, and the diverse needs of the community cannot be satisfied. The university has actually become an executive branch of the government, with a slow response to the society and the individual demands. In the governance mode, the government is no longer a single power center, non-governmental organizations, social groups, individuals and others are also power subjects. Now the social demand becomes increasingly diversified, if the government still relies on its own unilateral will, and plans the university development and personnel training in a unified model, it is obviously contrary to the requirements of the times. In addition, if the government forces too much, regardless of the preferences of citizens and social groups, and corporate interests, it often leads to a variety of escaping or boycott behaviors. What kind of universities to establish, how to set up the course, what kind of talents to train, and the direction of scientific research and so on, must be negotiated and jointly decided with the university and society, so as to meet different consumers' needs and different social needs. Therefore, only the government, the university, and the society cooperate with each other, can make the university academic governance more effective.

\section{CONCLUSION}

Along with the change of economy in the world, the internal situation of colleges has changed deeply, and the study of university academic management has become an important task of further development. The theory of governance, as a pluralistic, democratic and cooperative management idea, provides a new research perspective of university academic management for us. The introduction of it is integrated with the spirit of the times and modern meanings, providing a theoretical reference for the perfection of academic governance mechanism in university. The problem of university academic management is a systematic project. It is believed that with the deepening of the study and the improvement of governance theory, university academic management will certainly go toward the direction of more standardized and systematic development.

\section{REFERENCES}

[1] J. N. Rosenau. Governance without Government: Order and Change in World Politics[M].Cambridge University Press, 1992: 4.

[2] Kooiman, J. Governance and Governability: Using Complexity, Dynamaics and Diversity. InModern Governance, ed. J. kooiman. London: Sage, 1993: 4.

[3] Keping Yu. Governance and Good Governance. Beijing: Social Sciences Academic Press(China), 2000: 2-4. 